University of South Carolina

Scholar Commons

Fall 2000

\title{
Police Accountability and Early Warning Systems: Developing Policies and Programs
}

Geoffrey P. Alpert

University of South Carolina - Columbia, geoffa@mailbox.sc.edu

Samuel Walker

Follow this and additional works at: https://scholarcommons.sc.edu/crim_facpub

Part of the Law Enforcement and Corrections Commons

\section{Publication Info}

Published in Justice Research and Policy, Volume 2, Issue 2, Fall 2000, pages 59-72.

Alpert, G. and Walker, S. (2000). Police Accountability and Early Warning Systems: Developing Policies and Programs. Justice Research and Policy, 2(2), 59-72.

(C) 2000 Justice Research and Statistics Association.

This Article is brought to you by the Criminology and Criminal Justice at Scholar Commons. It has been accepted for inclusion in Faculty Publications by an authorized administrator of Scholar Commons. For more information, please contact digres@mailbox.sc.edu. 


\title{
POLICE ACCOUNTABILITY AND EARLY WARNING SYSTEMS: DEVELOPING POLICIES AND PROGRAMS
}

\author{
Geoffrey P. Alpert \\ University of South Carolina \\ Samuel Walker \\ University of $\mathrm{N}$ ebraska at $\mathrm{O}$ maha
}

\section{Abstract}

The identification of police officers who have potential problems has emerged as a popular approach for curbing police misconduct and achieving accountability. Early warning (EW) systems are data-driven programs whose purpose is to identify officers whose behavior is problematic and to subject those officers to some kind of intervention, often in the form of counseling or training. Because of their potential for providing timely data on officer performance and giving police managers a framew ork for correcting unacceptable performance, early warning systems are consistent with the new demands for performance evaluation raised by community policing and the effective strategic management of police departments. This article identifies essential components of EW systems and explains the characteristics, structure, and processes of a model program.

This research was supported by G rant N 0. 98-IJ-CX -0002 from the N ational Institute of Justice, O ffice of Justice Programs, U.S. D epartment of Justice. Points of view in this document are those of the authors and do not necessarily represent the official position or policies of the U.S. D epartment of Justice.

JUSTICE RESEARCH AN D POLICY, Vol. 2, N o. 2, Fall 2000

(c) 2000 J ustice Research and Statistics A ssociation 
Identifying police officers with potential problems has emerged as a popular approach to holding officers and agencies accountable and reducing officer misconduct. Early warning (EW) systems-structures set up to identify and intervene with officers who show signs of problematic behavior-were endorsed by the U.S. Commission on Civil Rights (1981) in 1981, and have recently formed the centerpiece of many agencies' accountability systems. At the end of the twentieth century, approximately $40 \%$ of all municipal and county law enforcement agencies serving populations greater than 50,000 people either had an EW system or were planning to implement one.

An EW system has three main components: 1) identification of officers whose behavior appears to be problematic; 2 ) intervention to correct the problematic behavior; and 3) a process to follow-up officers who have been subject to intervention. An EW system is "early" in the sense that a department acts on the basis of performance indicators that do not necessarily warrant formal disciplinary action, such as a pattern of unsustained complaints. It "warns" by placing an officer on a list indicating that special attention by his or her supervisor, or some other type of intervention, is warranted.

The current popularity of establishing an EW system to correct police misconduct and achieve accountability raises concerns both about the systems' impact and about the program elements necessary for effectiveness. Unfortunately little has been written on the subject and no outcome evaluation has been conducted (Walker, Alpert, \& Kenney, forthcoming; Kappeler, Sluder, \& Alpert, 1998). The purpose of this article is to identify essential components of EW systems and to explain the characteristics, structure, and processes of a model program.

\section{Acknowledging the Problem O fficer}

Interest in accountability systems in general and EW specifically has increased as growing evidence supports the perception that a small percentage of officers are responsible for a disproportionate share of citizen complaints and other concerns. Early reports on the phenomenon (Toch, 1975, and Goldstein, 1977) have been supported by more recent findings from authoritative bodies including the U.S. Department of Justice (1997) and the Christopher Commission (1991), which identified 44 "problem officers" in the Los Angeles Police Department with extremely high rates of complaints. The Commission noted that these officers were "readily identifiable" on the basis of existing agency records. While there has been some research conducted on problem officers, there have not been systematic procedures designed to identify, manage, and correct their behavior. 


\section{Turning Information Into a M anagement Tool}

The concept of EW is consistent with the basic principles of personnel management and human resource development that have developed in the private sector (M athis \& Jackson, 1999; Poole \& Warner, 1998). Employers recruit, select, and train employees to achieve the goals and objectives of the organization efficiently and effectively. Routine employee evaluations include the collection and assessment of specific performance measures. Additionally, an employee's immediate supervisor is charged with knowing the quantity and quality of the subordinate's performance ( $M$ athis \& Jackson). Routine and systematic performance evaluations coupled with a supervisor's first-hand knowledge of employees is theoretically sufficient to identify those employees whose performance is extraordinary, problematic, or inadequate (Redeker, 1989). H ow ever, even in well-functioning organizations, the knowledge of many employees' problematic behavior may "fall through the cracks" if there is no systematic method or procedure to identify the behavior and the officers. The problem is particularly acute in many law enforcement agencies, where misconduct is systematically excused. Prior to the development of an EW system as part of a consent decree settling a suit by the U.S. Justice Department, for example, the Pittsburgh police department maintained no systematic records of officer use of force. And in Los Angeles, a recent internal Board of Inquiry R eport found that the department's regular personnel evaluations were widely regarded as worthless by members of the department (Los Angeles Police D epartment, 2000).

The primary purpose of an EW system is to translate officer performance indicators into a formal management tool for identifying officers with potential behavioral problems. O nce a list of officers is generated, supervisors review each officer's full performance record to determine whether that officer represents a potential problem and is a candidate for intervention. The history of EW systems and examples of their management have been described elsewhere (Walker, A lpert, \& Kenney, forthcoming). Before we turn to a discussion of the various structures and processes of EW systems and to elements necessary for the development of a model program, we will present selected findings from a national survey of EW systems.

\section{N ational Survey of Early Warning Systems}

As part of the national evaluation of EW systems, the Police Executive R esearch Forum (PERF) surveyed 832 municipal and county police departments, as well as sheriff's departments serving populations of 50,000 people or more. Usable 
responses were received from 571 agencies, for a response rate of $69 \%$. The response rate was significantly higher for municipal agencies than for sheriff's departments. Complete results from this study are available elsewhere (Walker, Alpert, \& Kenney, 1999), but some of the results describe the prevalence of specific selection criteria, intervention, and follow-up procedures.

M ost systems are managed by the agency's internal affairs unit and the majority of EW systems use a combination of criteria, including use-of-force reports, citizen complaints, high speed pursuit reports, preventable damage to agency vehicles, involvement in civil litigation, and citizen complaints. Additionally, systems use different numbers of events and time frames to trigger an officer's inclusion on the list.

The national survey discovered that most $(73 \%)$ of the agencies use three use-of-force reports as the selection criterion. Similarly, more than three fourths (77\% ) use a 12-month time frame when counting these reports. A bout one third of all systems identify officers on the basis of "informal" performance review with no formal criteria. Other methods of inclusion are complaints made against the officer. When complaints are used, most (68\%) EW systems place an officer on their EW list on the basis of three complaints. A bout three quarters (76\%) of the systems use a 12-month time frame for counting the number of complaints. That is, most systems identify officers on the basis of three complaints or use-offorce reports within a 12-month period.

The majority (62\%) of the EW systems used a performance review or counseling session by the officer's immediate supervisor as the initial intervention. A bout half of all agencies (45\%) require officers who were identified by the EW system to attend a specialized training class as part of the intervention.

$\mathrm{N}$ inety percent of all EW systems monitor officers' performance following intervention. Of these, about 40\% monitor for a period of between 1 and 12 months. A nother 7\% monitor for a period of between 13 and 36 months. The remaining $53 \%$ did not specify the length of the monitoring period.

The national survey found a wide variety of EW systems functioning in law enforcement agencies throughout the country. The data provide a cursory description of the available programs and indicate the diversity and flexibility necessary in the planning and development of EW systems. Certainly these systems are complex, expensive, and high-maintenance operations that require a significant investment in personnel, data collection, and administrative oversight (Walker, Alpert, \& Kenney, 1999). The information generated from the national survey indicated that the three major elements of EW systems include selection criteria, intervention, and follow-up. O ur discussion now turns to those elements. 


\section{M odel Elements of an EW System}

The establishment of an effective and efficient EW system requires that the criteria for selection of officers to the system are linked to the needs of the agency, the intervention is linked to the needs of the officer, and the follow-up procedure links the officer's problematic behavior to the supervisor's style and ability.

\section{Selection Criteria}

EW systems use a variety of criteria for identifying potential problem officers and selecting them for intervention. Some systems rely solely on use-of-force reports and/or citizen complaints as selection criteria, while others rely on a broad range of performance indicators, including use-of-force reports, involvement in civil litigation, and violations of administrative rules (e.g., neglect of duty), among others. The use of multiple indicators provides a broader base of information than the sole reliance on citizen complaints, which are highly underreported (Walker \& Graham,1998). Similarly, relying on one type of event may mask behavioral issues that need to be addressed. M ultiple indicators are more likely to identify officers whose performance is genuinely problematic and who may be in need of some official intervention. These indicators should be determined by an analysis of agency history, culture, and potential problems. For example, the same criteria used in the process of officer selection could be used to monitor officer performance. Indicators including financial problems or driving records could be used in an EW system if those are issues of concern to the department (Kappler, Sluder, \& Alpert, 1998). If an agency is considering the creation or modification of an EW system, groups of officers and members of the community could be brought together to discuss alternative criteria. Each potential criterion should be considered for its utility and for related data collection and record keeping issues.

Some EW systems involve mandatory referral to intervention if an officer's performance meets certain criteria (e.g., three citizen complaints within 12 months). 0 ther systems are discretionary in the sense that the selection process involves a command review to determine whether the indicators of unsatisfactory performance are justified by assignment, special duties, or other peculiar situations. In these systems, some officers who are identified by the system will not be referred for intervention.

\section{Intervention}

EW systems use a variety of different interventions for officers who have been selected by the system. M ost EW systems include interventions that consist initially of an informal counseling session between the officer and his or her 
immediate supervisor. Because the session is informal and part of a data gathering technique, there may not be documentation of what occurred in the session. While it may be appropriate to keep the process informal and undocumented, it is possible that a supervisor would not critically evaluate an officer's behavior and could tell him or her not to worry about being included on the EW system. Therefore, an agency will have to determine whether to institute an informal or a formalized system of communication. Each choice has implications. The informal system would keep the information at the first-line supervisor's level, whereas the formalized system would cause the information to go through the chain of command, where it could be reviewed at several levels. The informal system would give more flexibility to the supervisor who could handle the officer with a great deal of discretion. The formal system would likely heighten the visibility of the counseling session and ensure that the supervisor's attention to the officer is serious and appropriate.

There are certain variations in an agency's way of conducting a counseling session. For example, an officer and his or her supervisor could meet individually, or the two could meet with a member of the Command staff or Internal Affairs. A nother model would include a group session or class, directed by an official whose primary identification is with the program and who has no personal ties to individual officers. $\mathrm{H}$ ere, the "counselor" may be more detached from the officer but may not know him or her as well. There is always the danger that a group approach could serve inadvertently to strengthen a sense of group solidarity among the officers in the class and reinforce undesirable performance or a sense of resentment against management.

Once the officers have participated in the counseling session, they can be classified into a group that needs no further monitoring or a group that needs follow-up. The agency can determine whether monitoring is mandatory or at a supervisor's discretion. If it is decided that an officer's behavior was reasonable and there were justifications for the actions, it may be decided that the officer needs no further attention or only limited attention. For example, it could be that an officer qualified for the EW list because of a number of use-of-force reports. Upon examination, it becomes clear that the officer was involved in several narcotics arrests where the suspects were resisting, but there were no complaints of excessive force. In this type of situation, the officer could be informed that the force used was justified by the assignment but that his or her numbers were being scrutinized. H owever, it also could be that an officer qualified for the list by having several complaints over a specified period, and a review of his or her record indicates more than 40 complaints over a period of 25 years. $\mathrm{H}$ ere a supervisor could go through the complaints and look at the similarities or trends and discuss them with the officer. 


\section{Post-I ntervention Follow-up}

The final system element involves the follow-up monitoring of officers after the intervention. The national survey data indicate that many programs claim to engage in follow-up monitoring. Unfortunately, the data from the national survey do not indicate the level of monitoring, which may involve only the expectation that a supervisor will keep an eye on the officer's performance. This is an element of EW systems about which very littleis known and more research is needed.

Post-intervention follow-up ranges from a mere hope for supervision to lengthy and formal monitoring, complete with specific reports and performance evaluations. An agency involved in an EW system will have to determine how much of the supervisor's behavior it wants to monitor. That is, a system that requires weekly or biweekly reports from supervisors will be putting them on notice that the officer's behavior should have been noticed before he or she was added to the EW list. As noted above, this approach requires a considerable departmental investment in administrative attention, paperwork, and data collection.

Different approaches to monitoring place the burden of responsibility on the officer, the supervisor, or the agency. Each department must select its own method of monitoring that fits the agency's culture and style. Certainly, different officers or officers who are on the list for different reasons could have a monitoring scheme designed to achieve a specific level of supervision or a specific purpose. In other words, an officer could help design his or her specific monitoring system, including benchmarks and objective goals. O ne excellent example of an EW system comes from the City of $\mathrm{M}$ iami.

\section{An Established Early Warning System: The City of M iami}

M ost EW systems are relatively new, having been created within the last few years. The EW system in the City of M iami Police Department is a useful example of a model program because it has been in existence for 20 years and presumably has resolved the problems that inevitably beset new and complex administrative systems.

The EW system in the M iami Police Department had its start in the late 1970 s and has developed into a comprehensive program for monitoring officers' performance. In 1979, the City of M iami Police Department's command staff, concerned with the nature and extent of citizen complaints, designed a system to identify those officers whose behavior created real or perceived problems with the public. The original idea was to create a model through which an officer's behavior gets evaluated, strategies are developed to address a diagnosis, programs for improvement are implemented, and the results are evaluated. The pro- 
gram began by searching officers' records and identifying those who had two or more citizen complaints between 1976 and 1978. The information collected showed that the average number of complaints filed against a $M$ iami police officer was .65 per year and 1.3 complaints for two years. Interestingly, 5\% of the officers accounted for $25 \%$ of all complaints. The implication was clear: a small number of officers was responsible for a disproportionate number of citizen complaints. Additionally, the search discovered that the officers with the most complaints were assigned to midnight shift. The data collected in the 1970s in M iami showed a trend that continues to exist in many agencies today. The M iami EW system has since evolved into one of the more comprehensive approaches to monitoring police officers in the United States. M ost importantly, it has developed a broad range of performance indicators.

The M iami EW system currently uses four categories of behavior as selection criteria for identifying officers (D epartmental O rder 2, Chapter 8). These data, which are routinely collected by a member of the Internal Affairs Unit and entered into a database, include the following:

1. Complaints - A list of all officers with five or more complaints, with a finding of sustained or inconclusive, for the previous two years.

2. Control of Persons (U se of Force) - A list of all officers involved as principals in five or more control-of-persons incidents for the previous two years.

3. Reprimands - A list of all officers with five or more reprimands for the previous two years.

4. D ischarge of Firearms - A list of all officers with three or more dischargeof-firearms incidents for the previous five years.

As officers are identified by the system, their supervisors are notified by an official memorandum. The supervisor is then responsible for meeting with the officer and determining whether he or she needs any assistance, counseling, training, or other intervention. The supervisor evaluates the officer's behavior to determine whether it was consistent with agency policies and professional standards (e.g., use of force justified by the circumstances; citizen complaint without merit), or whether there are behavior problems (e.g., unjustified use of force) that require attention. Certainly not all officers identified by the performance indicators and placed on EW will be referred for intervention.

In the case of officers requiring formal intervention, the supervisor then writes a memorandum recommending one of the following:

1. reassignment

2. retraining

3. transfer 
4. referral to an employee assistance program

5. fitness for duty evaluation, or

6. dismissal pursuant to civil service rules and regulations.

The supervisor's memorandum goes to the Commander of Internal Affairs through the chain of command. Each reviewing supervisor must agree or disagree with the recommendation. It is important to note that unlike some other EW systems, the M iami system ensures that a number of supervisors are involved in decisions related to potential problem officers, with the result that these decisions represent a consensus of opinion.

The City of M iami Police Department's EW system has been in operation for more than 20 years. $M$ any aspects of this program could be identified as a "best practice" and adopted by other agencies, but agencies interested in developing an EW system must examine their own needs, departmental culture, and desired outcome before designing and implementing an EW system. For example, the $M$ iami system is housed within the Internal Affairs Unit and currently uses complaints only if they are sustained or inconclusive. It also uses a time frame of two years when screening for most of its selection criteria. But these aspects of selection, among others, must be reviewed and assessed by each agency as it determines what is necessary and appropriate. Depending upon the type of agency and number of officers caught in the EW net, all open complaints could be used or they could be selected by type or status. Certainly, the time frame is a critical issue for managers to select. There is not "one best way"; each decision must be supported and justified.

In its July 2000 report, The City of M iami Police Department had approximately 1,100 sworn officers. There were 8 officers identified by the EW system, none in EW system I (complaints), 4 in EW system II (control of persons), 1 in EW system III (reprimands) and 3 in EW system IV (discharge of firearms).

\section{Intended Targets of EW Systems}

Early warning systems should be understood to have three different targetsindividual officers, supervisors, and departments- just as in the private sector, human resource development is seen as operating at three levels - the individual, thegroup, and the organization (Walker, Alpert, \& Kenney, 1999; Poole \& Warner, 1998). Clearly some officers who are on the list are there because of special assignments and related activities. 0 thers who are subject to intervention are readily rehabilitated once they acknowledge their problems and are receptive to 
suggestions for improvement. 0 thers are potentially "salvageable" as good police officers, but would require both considerable investment of effort by the department and commitment on the officer's part. At the other extreme, however, are some officers who may reject any suggestion that they have done anything wrong and may not be "salvageable." It is possible that some of these officers should not have been hired as police officers in the first place. 0 thers may have become so deeply ingrained in certain attitudes and behavior patterns that they are unable (or unwilling) to change.

Although EW systems are generally considered systems for improving the behavior of individual officers, a properly functioning system is directed as much toward supervisors as officers. That is, EW systems place supervisors on notice that it is their responsibility to closely monitor officers who have been subject to the program. Thus, the behavior of the supervisor is as much at issue as is the behavior of the subject officer. Clearly a good supervisor should be aware of a problem officer before he or she is flagged by a formal EW system. H owever, a formal EW system can help sergeants perform their duties by focusing on their officers' performance. An EW system can help keep some problem officers from "slipping through the cracks."

The final impact of an EW system is on the organization as a whole. In theory, information derived through the EW system (e.g., frequent citizen complaints related to a particular enforcement practice or a specific unit) is used to effect changes in policies and procedures, and/or training. Presumptively, such changes can help reduce the existing problems and help the organization achieve its official goals of protecting life and ensuring public safety. In this respect, an EW system can contribute to a police department becoming a "learning organization" (Geller, 1997).

In a police department that has no serious commitment to accountability and integrity, where serious forms of misconduct are not punished, an EW system will probably have little, if any, impact. In this context, the program will become just another formal bureaucratic procedure, empty of meaningful content. The potential contributions of an EW system will simply be overwhelmed by the failure of the department to investigate alleged misconduct and discipline officers appropriately. An EW system should be thought of as an administrative tool designed to support a properly functioning system of accountability. In the absence of a properly functioning system, it is not likely to make any real contribution by itself. At the other end of the scale, in a hypothetically ideal police department with the highest standards of integrity, an EW system is unnecessary. In such an organization, potential problems are already being addressed. O bviously, the ideal does not exist in any known police department, any more than it exists in any other public or private organization. 
The vast majority of police departments fall into the broad middle category, with some on-the-street problems and some commitment to accountability. To repeat the essential point made above, an EW system is an administrative tool that supports the basic system of accountability. The impact will vary from department to department according to the strength of the existing system. In departments with a recent history of accountability problems (e.g., frequent corruption allegations, recurring civil litigation, and high damage awards), the EW system will serve as notice to officers that the department is serious about eliminating improper conduct. It will also serve to identify and intervene with officers with recurring serious performance problems. In departments with comparatively high standards of accountability and relatively rare instances of serious misconduct, the EW system will primarily serve an integrity maintenance function. That is, the impact will fall primarily on supervisors to ensure that potential problems do not "slip through the cracks," as noted above.

\section{Implementing EW Systems}

The national survey finding that EW systems are complex administrative systems requiring considerable administrative attention, and not mechanical systems that function somewhat automatically, raises a number of concerns about successful implementation.

Perhaps the most serious concern is the danger that some police departments may create an EW system but fail to provide sufficient administrative oversight to ensure that the program remains a serious part of the administrative structure. Agencies do not need to rush to establish an EW system without determining and assigning the necessary resources and administrative support. For example, an agency that selects use of force reports as a criterion had better require such reports and be able to track them to determine if an officer has been involved in a series of incidents. Similarly, if involvement in civil suits is to be used as a criterion, it is important to ensure that these data are properly collected from the relevant government agencies and entered into the EW system in a timely manner. In other words, selection criteria must be chosen with caution and with the knowledge of how to manage and interpret the information systematically. The individual who collects and codes the information must have sufficient resources to complete the assignment. There must be a system of checks and balances to assure that all the information is collected and analyzed to determine if an officer belongs on the EW system. Additionally, supervisors must understand the operational aspects and importance of the EW system. 
There are many decisions an agency must make concerning the development and implementation of its system. For example, are open, unsubstantiated, defunct or withdrawn complaints to be included as part of an EW system? By not including them, officers might receive a large number of complaints without being flagged. Similarly, if only closed reports are considered, then it may be years after a behavioral concern developed that an officer was noticed.

The timing of reports is another issue that policymakers al ways face. If there are only annual reports, the system may not identify some officers on a timely basis, whereas monthly reports should identify officers early, when the warning is most important. Choosing the administrative home for the EW system is another critical decision. M ost often, the internal affairs division administers the EW system. Internal affairs is a natural "home" for an EW system if it is the division in which data on officers are maintained. O nce collected, the data can be entered into a computer for analysis, and lists of officers who fit the criteria can be generated and sent to supervisors.

An agency that is planning to develop an EW system must educate its supervisors about its implementation and importance. Supervisors should understand the goals, objectives, management issues, and potential problems related to the system, as well as the justification, support, and agency interpretation for each system element.

\section{Conclusion}

Early warning (EW) systems have emerged as a popular remedy for police misconduct. EW systems vary considerably in terms of their formal program content, specifically with respect to selection criteria, the nature of the intervention, and post-intervention follow-up. They are a potentially important management tool for the control of police officer misconduct and for promoting standards of accountability within a law enforcement agency, though they are expensive, complex, high-maintenance operations requiring a significant investment of administrative resources. There is some evidence that some EW systems are essentially symbolic gestures with little substantive content.

An effective EW system must have the following elements. First, the criteria for identifying "problem" officers should encompass a broad range of performance indicators and not belimited just to citizen complaints. Second, any intervention should involve more than an officer's immediate supervisor to ensure that individual supervisors do not covertly undermine the goals of the program. Third, there should be some post-intervention monitoring of officers by supervisors. Post-intervention monitoring is designed not only to identify cases in which 
patterns of serious misconduct continue, but also to communicate a message to subject officers that their performance is being closely scrutinized. Equally important, the monitoring places immediate supervisors on notice that their responsibilities include the close monitoring of officers whose performance is problematic.

An EW system is no panacea for problems of misconduct and a lack of accountability. It should be seen as one part of a system of accountability. In a law enforcement agency without effective accountability measures in place, it is unlikely that an EW system will have much, if any, effect. At the same time, in an agency that has made a commitment to accountability, an EW system can serve as one of several management tools designed to curb misconduct, increase the level of trust and confidence in the police, and raise the quality of services delivered to the public. 


\section{References}

Christopher Commission. (1991). Report of the Independent Commission on the L os Angeles Police D epartment. Los Angeles: Author.

Geller, W. A. (1997, December). Suppose we were really serious about police departments becoming learning organizations? N ational Institute of J ustice Journal, N 0.234 , pp. 2-8.

Goldstein, H . (1977). Policing a free society. Cambridge: Ballinger.

Kappeler, V., Sluder, R ., \& Alpert, G . (1998). Forces of deviance: Understanding the dark side of policing. Prospect H eights, IL: Waveland Press.

Los Angeles Police Department. (2000) Board of Inquiry report. Los Angeles: A uthor.

M athis, R. L., \& Jackson, J. H. (Eds.). (1999). H uman resource management: Essential perspectives. Cincinnati: Southwestern College Publishing.

Poole, M ., \& Warner, M . (1998). The IEBM handbook of human resource management. London: International Thomson Business Press.

Redeker, J. (1989). Employee discipline: Policies and practices. Washington, DC: Bureau of $\mathrm{N}$ ational Affairs, Inc.

Toch, H., Grant, J. D., \& Galvin, R. T. (1975). A gents of change. N ew York: John Wiley.

U.S. Commission on Civil Rights. (1981). Who is guarding the guardians. Washington DC: Author.

U.S. Department of J ustice. (1997). Police integrity: Public service with honor. Washington: Government Printing O ffice.

Walker, S., Alpert, G. P., \& Kenney, D. J. (1999, O ctober) Responding to the problem officer: A national study of early warning systems. (A final report to the $\mathrm{N}$ ational Institute of J ustice.) Washington, DC: N ational Institute of J ustice.

Walker, S., Alpert, G. P., \& Kenney, D. J. (in press). Early warning systems for police: Concept, history and issues. Police Q uarterly.

Walker, S., \& Graham, N . (1998). Citizen complaints in response to police misconduct: The results of a victimization survey. Police $Q$ uarterly $1,65-90$. 